\title{
MYOCARDIAL CHANGES OCCURRING IN POTASSIUM DEFICIENCY
}

\author{
BY \\ P. M. MCALLEN \\ From the West Middlesex Hospital \\ Received June 11, 1954
}

Potassium has been recognized as essential for normal function of the myocardium since Ringer's studies in 1883. A deficiency of potassium may affect the heart in the human subject and result in a fall of the systolic blood pressure, in the appearance of abnormalities in the electrocardiogram (Bellet et al., 1949; McAllen, 1951; Surawicz and Lepeschkin, 1953), and possibly in the development of acute heart failure (Goodof and MacBryde, 1944; Frenkel et al., 1947; Gamble et al., 1948).

Few pathological observations have been made on the hearts of patients with potassium deficiency, although much information is available from animal experiments. Follis et al. (1942) studied rats on a diet deficient in potassium and found constant changes in the myocardium and in the kidneys. After eight days on the diet, multiple small areas of muscle necrosis appeared. Concurrently, these areas were infiltrated first by polymorphonuclear leucocytes and later by mononuclear cells. These changes occurred in auricular and ventricular muscle. During the next few weeks the focal lesions increased in size and number, and by the sixth week proliferation of connective tissue had begun in the areas first affected. At the forty-seventh week, there was extensive fibrosis but occasional early type lesions were still appearing. The potassium content of the heart muscle of these animals was 35 per cent lower than normal controls. In the kidneys, there was dilatation of the convoluted tubules with necrosis of the lining epithelium. Other workers confirmed these findings and showed also that the longer the duration of the low potassium state the more extensive the cardiac damage, and further, that potassium chloride added to the drinking water prevented the development of the myocardial lesions (Darrow and Miller, 1942; Smith et al., 1950; Peschel et al., 1951; French, 1952). Similar changes have been found at autopsy in a few human subjects and these lesions have been attributed to potassium deficiency (Goodof and MacBryde, 1944; Roderiguez et al., Cases 1 and 2, 1950; Perkins et al., 1950; Luft et al., Case 1, 1951; Keye, 1952). In half of these cases the evidence of potassium deficiency was clinical alone, and the duration of the condition was a few days only in all but two cases.

This report presents the clinical, biochemical, and necropsy findings in two well established cases of prolonged potassium deficiency. In each case extensive myocardial lesions were present.

\section{CASE REPORTS}

Case 1. A man, aged 41 years, had idiopathic steatorrhœa with muscular weakness of four months duration. When admitted to hospital on May 18, 1950, the patient was very weak in all limbs and unable to sit up. Clinical examination of the heart was normal. The blood pressure was $95 / 50$. An X-ray of the heart and lungs revealed no abnormality. The hæmoglobin was $11.5 \mathrm{~g}$. per $100 \mathrm{ml}$. and the red cells were 3,560,000 per c.mm. The Wassermann reaction was negative. Blood chemistry values per $100 \mathrm{ml}$. of serum were: sodium $295 \mathrm{mg}$., potassium 12.1 mg., chlorides (as sodium chloride) $620 \mathrm{mg}$., calcium $8.3 \mathrm{mg}$., phosphorus $1.9 \mathrm{mg}$. The electrocardiogram showed a flat $\mathrm{T}$ wave in the standard leads and a slight depression of the S-T segment with an inverted $T$ wave in leads V3 and V5 (Fig. 1A). These changes disappeared in later tracings when the serum potassium was normal. 
Potassium chloride $10 \mathrm{~g}$. daily was given orally for the first four days, and on this therapy the weakness lessened and the level of serum potassium became normal. Folic acid and a diet of low fat and high protein content produced general improvement. The blood pressure rose to 130/70. After five weeks, the patient was discharged home and he remained well with normal bowel action for the next two years.

Early in 1953, severe diarrhœa recurred and the patient was re-admitted to hospital on February 3, 1953. He was dehydrated, weak, and all peripheral reflexes were diminished. The heart sounds were normal and there were no murmurs. The blood pressure was $98 / 55$. The hæmoglobin was: $12 \cdot 1 \mathrm{~g}$. per $100 \mathrm{ml}$. and the red cells were 4,400,000 per c.mm. Blood chemistry values per $100 \mathrm{ml}$. of serum were: sodium $272 \mathrm{mg}$., potassium $12.0 \mathrm{mg}$., calcium $9.6 \mathrm{mg}$., total proteins $3.2 \mathrm{~g}$., albumin $2 \cdot 1 \mathrm{~g}$., and globulin $1.1 \mathrm{~g}$.

He was given penicillin, aureomycin, folic acid, parenteral liver extract, blood transfusions, oral and intravenous saline, and oral potassium chloride $5 \mathrm{~g}$. daily, but failed to improve. He was uncooperative, 
and would only take a diet very low in protein. After two weeks, he developed œdema of sacrum and legs. At this time, the jugular venous pressure was not raised and the heart sounds were unchanged. A few days later light jaundice appeared with bile pigments in the urine. Liver function tests showed: serum bilirubin $3.9 \mathrm{mg}$. per $100 \mathrm{ml}$., alkaline phosphatase $50 \mathrm{King}$-Armstrong units per $100 \mathrm{ml}$., thymol turbidity 1 unit, thymol flocculation negative, and serum gold reaction negative. The serum potassium values remained low (11-14 mg. per $100 \mathrm{ml}$.). Even after increasing the oral potassium chloride dosage to $15 \mathrm{~g}$. daily the serum potassium reached normal values on occasional days only. During the fourth and fifth weeks the œdema, jaundice, and diarrhœa persisted. He became drowsy, very weak, and died on March 10, 1953.

During this last admission the electrocardiographic changes were slight. When the serum potassium was low the S-T segment was depressed in leads V3 and V5 (Fig. 1B). A normal tracing was obtained when the serum potassium was within normal limits (Fig. 1C).

An electrolyte balance was carried out two weeks before death. This showed a retention of sodium and a markedly negative balance for potassium, the latter being attributable to an abnormal loss of potassium in the stools.

Necropsy (body weight, $55 \mathrm{~kg}$.). The heart weighed $240 \mathrm{~g}$. All valve orifices and cusps were normal. The myocardium was of normal thickness and no fibrosis was visible. Detailed dissection of the coronary artery system showed healthy vessels with no atheroma, narrowing, or occlusion. In the lungs a suppurative bronchiolitis was present. The liver on section showed a pattern of zonal pallor, and the bilary system was free from obstruction. The remaining organs showed no significant change.

Histology. In all parts of the myocardium there were foci showing loss of striation of the muscle fibres (Fig. 3), and sometimes vacuolation (Fig. 4). The nuclei of the myocardial fibres in these areas varied markedly in size, shape, and depth of staining. Small collections of monocytes and lymphocytes, and

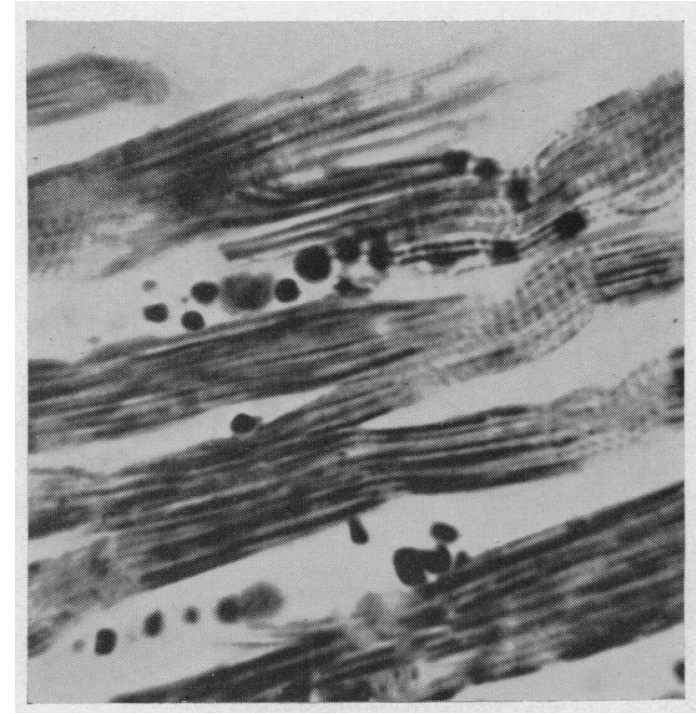

FIG. 3.-Case 1. Area of left ventricle showing transition from normal muscle fibres to muscle fibres with loss of cross striation. Heidenhain's stain $(\times 380)$.

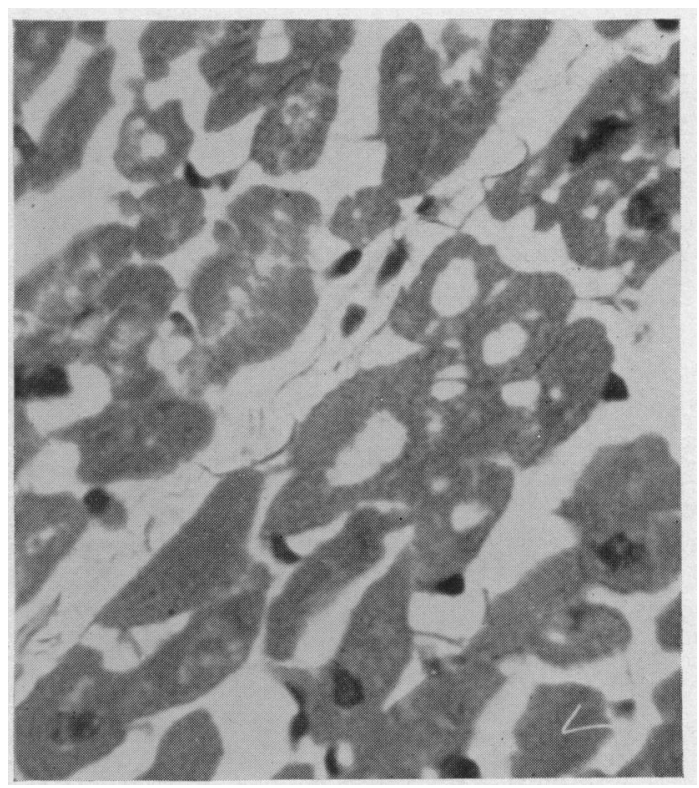

FIG. 4.-Case 1. Vacuolation of muscle fibres in right ventricle. H. and E. $(\times 380)$. The vacuoles did not react to stains for fat or glycogen.

increased numbers of fibroblasts were seen in the interstitial tissue. Fibrous tissue frequently occurred as bands between muscle fibres (Fig. 5) and occasionally as small areas of muscle replacement (Fig. 6). All sections of the coronary arteries were free from abnormality. In the liver there was fatty change in the peripheral zones of the lobules. Sections of the small intestine showed a dense and extensive lymphocytic infiltration of the mucosal and submucosal layers. In the renal tubules some dilatation was present but no vacuolation or necrosis of the lining epithelium. 


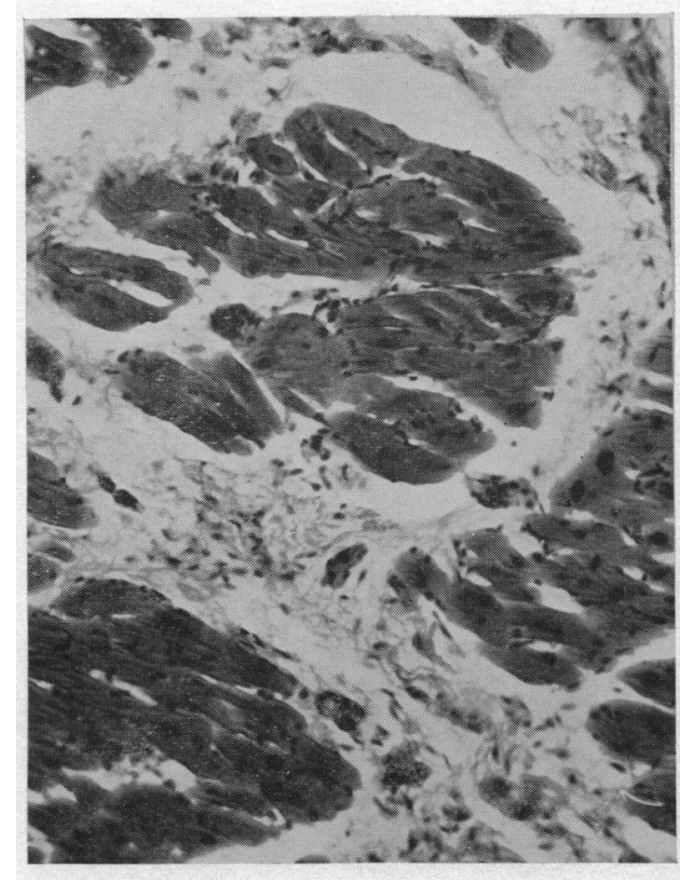

Fig. 5.-Case 1. Bands of fibrous tissue in right ventricle. H. and E. $(\times 80)$.

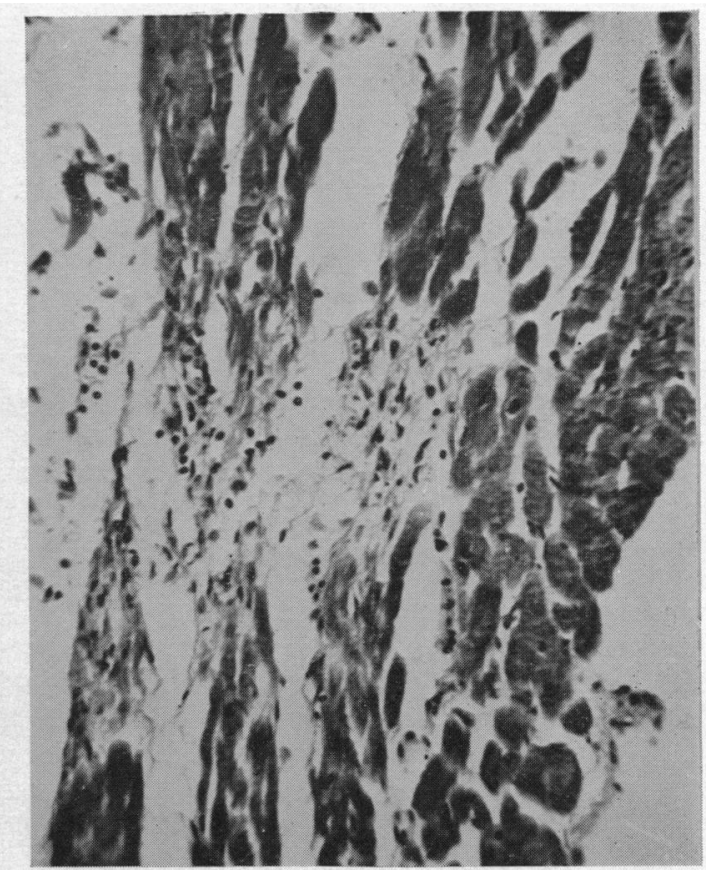

FIG. 6.-Case 1. Focus of fibrosis replacing muscle in left ventricle. There is a cell infiltrate consisting mainly of lymphocytes. H. and E. $(\times 80)$.

Potassium Content of Heart Muscle. A piece of the left ventricle was chemically analysed and found to contain $15 \mathrm{mg}$. of potassium per $100 \mathrm{~g}$. of wet tissue. This represents a greatly reduced content, the average normal value being a little over $300 \mathrm{mg}$. per $100 \mathrm{~g}$. of wet tissue (Iseri et al., 1952; Clarke and Mosher, 1952).

Case 2. A woman of 49 , suffering from chronic ulcerative colitis, had attacks of marked muscular weakness due to potassium deficiency which began in 1948. Previously reported studies (Lubran and McAllen, Case 1, 1951) showed that this deficiency was dependent on a large potassium loss in the stools. On examination, the heart sounds were normal and there were no murmurs. The blood pressure was 110/70. The blood Wassermann and Kahn reactions were negative. An X-ray of the heart was normal in size and outline. The electrocardiogram showed a depressed S-T segment, an abnormally low or inverted $T$ wave, and a large $U$ wave when the serum potassium was low, but no abnormality when the serum potassium was normal (Fig. 2, and also figures previously presented, McAllen, Case 3, 1951).

During 1948 and 1949, the colitis fluctuated in degree and was mostly severe. A daily maintenance dose of 8-10 g. of potassium chloride was regularly required to prevent the attacks of muscular weakness recurring. Often this large daily dose only maintained the fasting serum potassium around a level of $12 \mathrm{mg}$. per $100 \mathrm{ml}$.

On March 3, 1950, the patient suddenly became unconscious and was admitted to hospital. There had been retrosternal pain for the previous twenty-four hours. Examination of the heart now revealed a soft apical systolic murmur and triple rhythm. The blood pressure was 100/70. No localizing signs were present in the central nervous system. A lumber puncture produced a clear fluid which was found to contain $72 \mathrm{mg}$. of protein per $100 \mathrm{ml}$. but was otherwise normal.. Serum potassium was $11.0 \mathrm{mg}$. per $100 \mathrm{ml}$. The electrocardiogram (Fig. 7A) was quite unlike the tracings taken previously at a similar level of serum potassium (Fig. 2B) and showed changes considered to be those of a recent anterior myocardial infarct. The patient was thought to have had associated cerebral embolism. She regained consciousness after seven hours.

On March 8, the left femoral artery became suddenly occluded. An embolus was removed from the bifurcation of the left common iliac artery, but amputation of the leg became necessary. Subsequent 

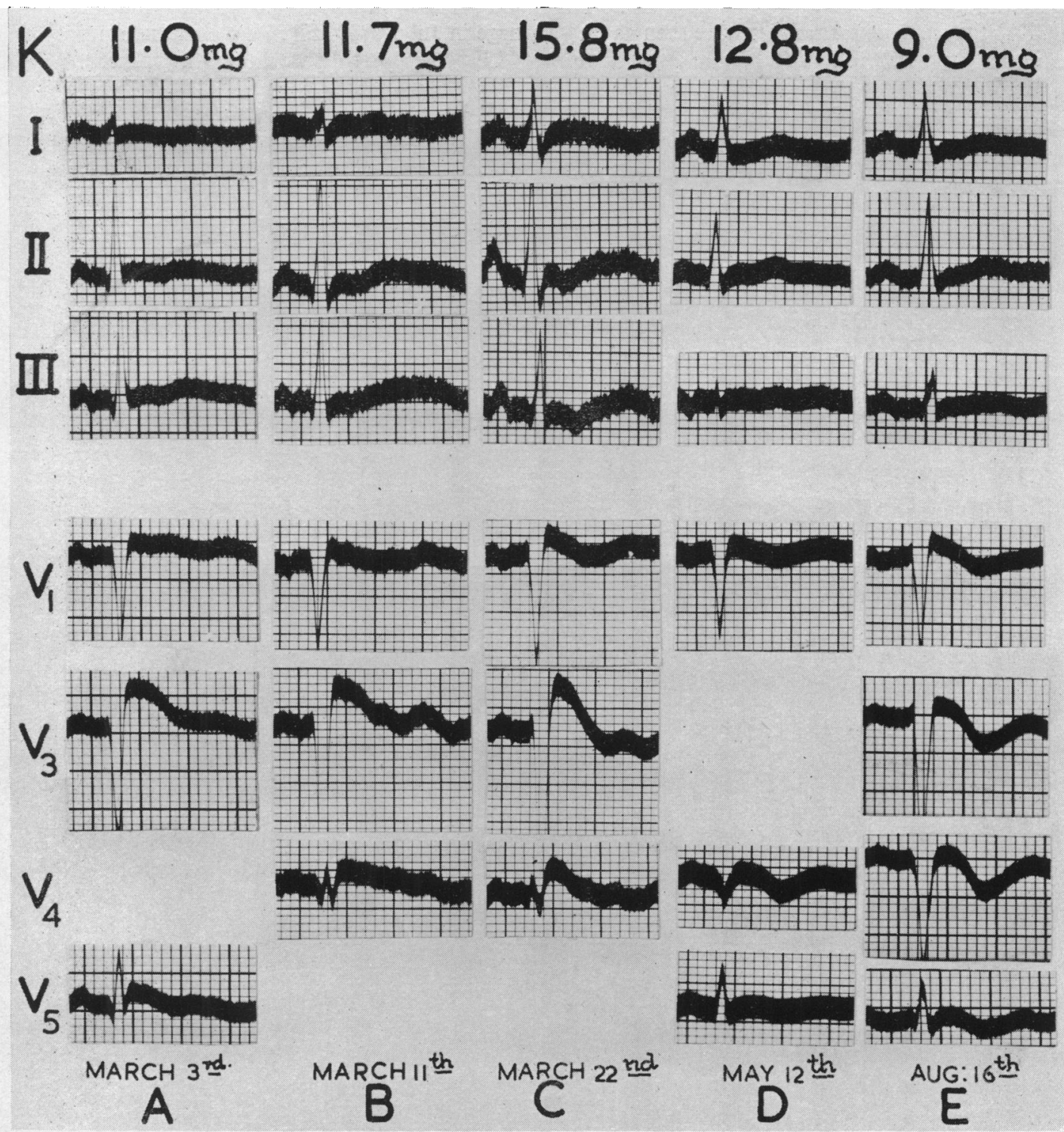

IG. 7.-Case 2. Serial electrocardiograms taken during 1950 with simultaneous serum potassium levels. (A) March 3, the S-T segment is abnormally elevated in leads II, III, V3, and V5, the T wave is low in all leads, and the $U$ wave is inconspicuous. (B) March 11, and (C) March 22. The tracings on both days are similar to those on March 3, and are little affected by the differences in the level of the serum potassium. A pathological $Q$ wave is seen in lead V4. (D) May 12, and (E) August 16. The $S-T$ segment is no longer elevated, the $T$ wave has become inverted in leads $V 3$ and $V 5$, and the $Q$ wave persists in lead V4. (Administration of $10 \mathrm{~g}$. of oral potassium chloride at this time did not correct the abnormalities but increased the inversion of the $\mathrm{T}$ wave.)

electrocardiograms (Fig. 7B-E) showed serial changes in the S-T segment and T wave, together with pathological Q waves, typical of cardiac infarction. The patient was discharged home on July 22, 1950.

During 1951, there was a further severe exacerbation of diarrhoa. The patient would not attend hospital for some months and no potassium salts were taken. Eventually, bouts of muscular weakness returned and became incapacitating. At this time, a second attack of retrosternal pain occurred and one week later, October 25, 1951, the patient was re-admitted to hospital. On examination, there were no 
abnormal signs in the cardiovascular system. The blood pressure was 140/90. In the electrocardiogram (Fig. 8A) the same abnormalities were seen as on discharge in July, 1950 (Fig. 7E). The serum potassium was $13.0 \mathrm{mg}$. per $100 \mathrm{ml}$. After seven days' treatment with potassium salts weakness disappeared.

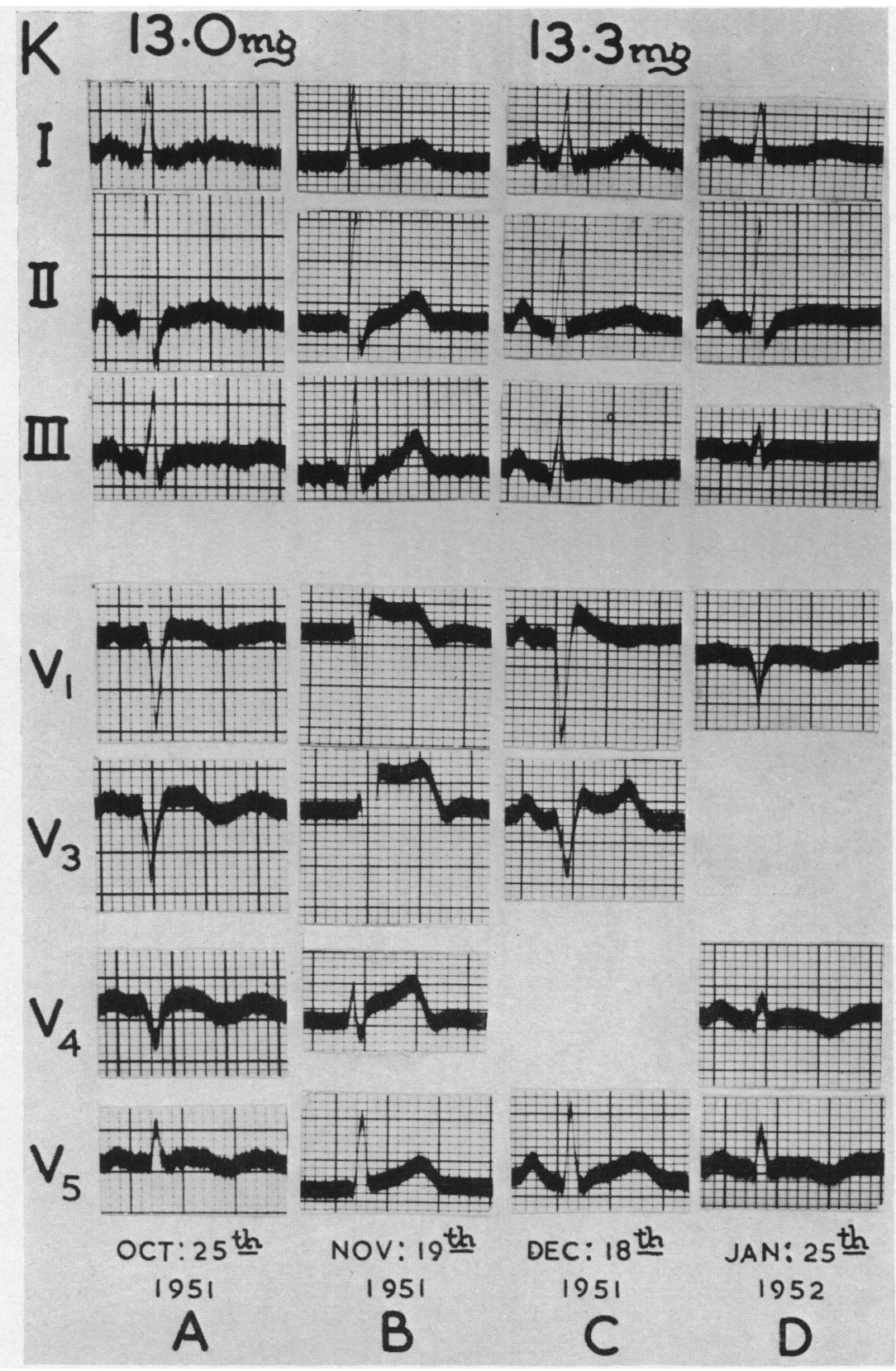

FIG. 8.-Case 2. Electrocardiograms taken during 1951 and 1952. (A) October 25, 1951. The abnormalities present are similar to those of August 16, 1950 (Fig. 7E). (B) November 19, 1951. In all leads there is an elevation of the S-T segment and an increase in voltage of the $T$ wave. The rhythm is apparently nodal. (C) December 12, 1951, and (D) January 25, 1952. These tracings show gradual disappearance of the elevation of the $S-T$ segment, and fall of the $T$ wave to the previous low voltage or inversion. Sinus rhythm has returned. 
On November 19, 1951, a third attack of severe lower sternal pain developed. Examination of the heart at this time did not reveal triple rhythm or any murmurs. The blood pressure was now 90/60. An electrocardiogram (Fig. 8B) showed a new elevation of the S-T segment in all leads indicating further damage to the myocardium. The pain disappeared after forty-eight hours. Subsequent tracings over the next two months (Fig. $8 \mathrm{C}$ and D) showed a gradual disappearance of the recent changes but a persistence of the old abnormalities. The serum potassium level over this period was usually below normal.

On February 1, 1952, the patient suddenly developed a right hemiplegia and also occlusion of the right femoral artery. An embolus was shortly removed from the femoral artery but the patient died ten hours after operation.

Necropsy (body weight $50 \mathrm{~kg}$.). The heart weighed $245 \mathrm{~g}$. In the left ventricle (thickness up to $1.4 \mathrm{~cm}$.) there was an area of fibrosis and thinning $(2 \times 2.5 \mathrm{~cm}$.) involving the apex anteriorly and the adjacent part of the interventricular septum. A recent antemortem thrombus $(1.5 \times 1 \times 1 \mathrm{~cm}$.) was present on the endocardial surface of the fibrosed area. Appearances of the right ventricle and both auricles were normal. All valves were normal. Healthy and full-sized coronary ostia were present. Both coronary arteries and their branches were completely free from narrowing or occlusion, and showed only occasional, small, scarcely raised, flecks of atheroma. The smaller divisions of these arteries were dissected and found to be free from disease. In the aorta and other systemic arteries there was no atheroma. The colon showed the appearance of the late fibrous stage of chronic ulcerative colitis. The left kidney (weight $145 \mathrm{~g}$.) had a capsule that stripped with difficulty and a finely granular surface. On section the pattern was normal. The right kidney was absent (nephrectomy for renal abscess in 1938). In the brain there was an embolus in the left middle cerebral artery.

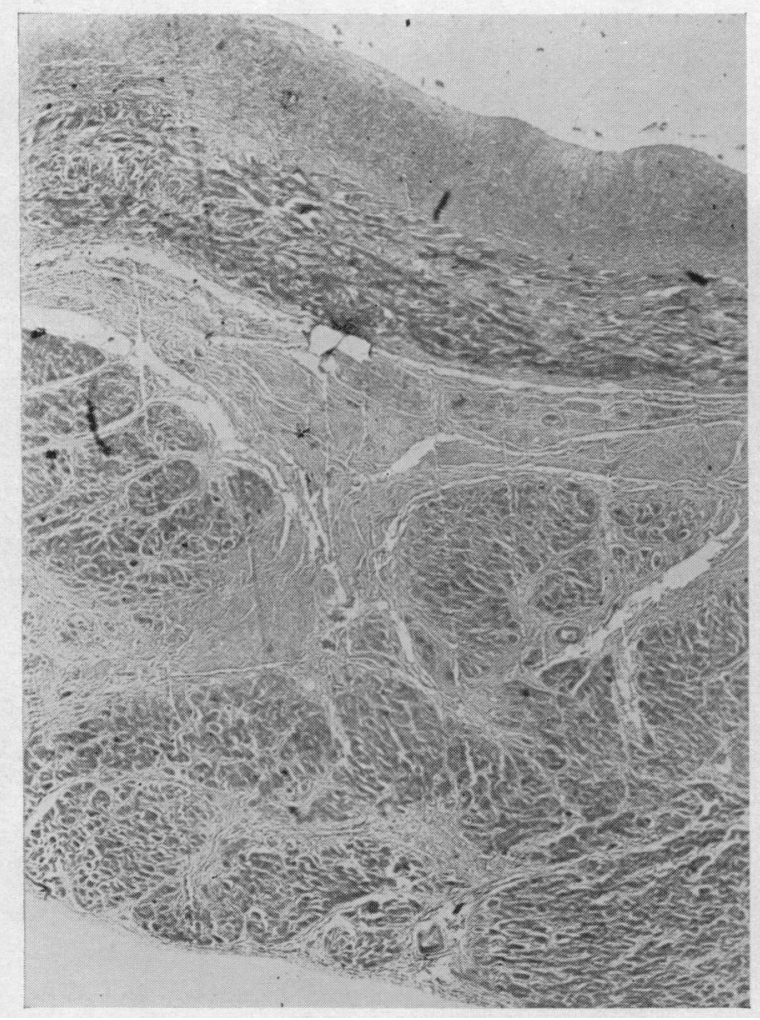

FIG. 9.-Case 2. Low-power view of a section through the scarred area at the apex of the left ventricle. Strands of fibrous tissue are seen throughout the whole thickness of the myocardium and are gathered into dense bands in its middle third. The endocardium is locally thickened by fibrosis. H. and E. $(\times 20)$.

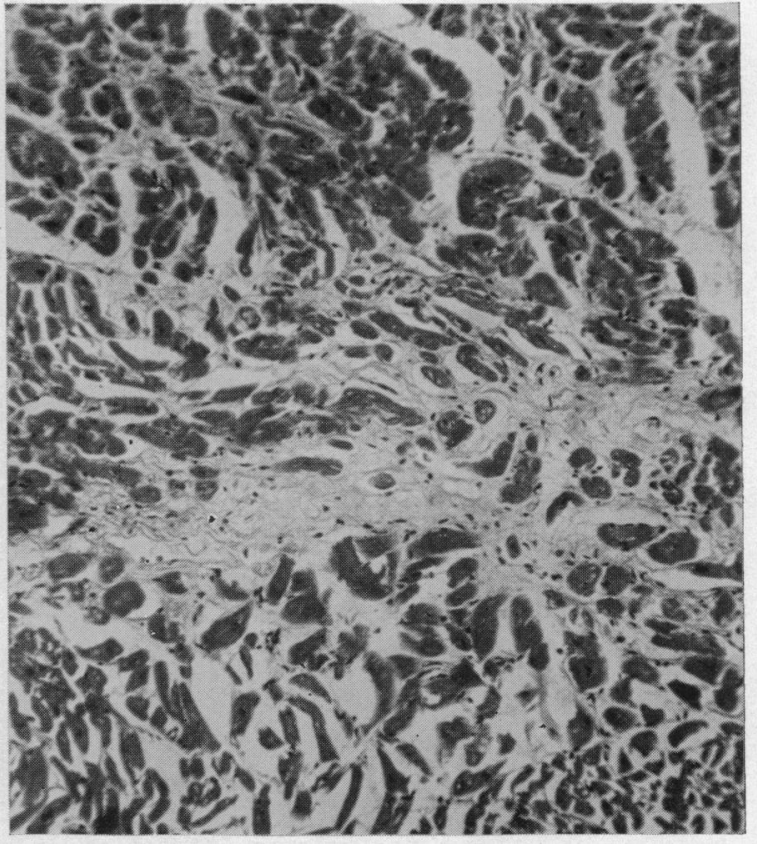

Fig. 10.-Case 2. Small focus of fibrosis in the myocardium of the left ventricle. H. and E. $(\times 380)$. 
Histology. The scarred area at the apex of the left ventricle showed bands of fibrous tissue of varying size running throughout the whole thickness of the myocardium (Fig. 9). Fibrosis was also seen in the remainder of the left ventricle, but mainly as multiple small foci unrelated to blood vessels (Fig. 10). Similar focal fibrosis was present in all parts of the right ventricle and both auricles. The fibroblasts between the muscle fibres were frequently increased in number and collected into groups. There were also occasional small collections of polymorphonuclear leucocytes between the muscle fibres. Examination of the coronary artery system showed only slight diffuse concentric fibrous endarteritis in the larger vessels. Sections of the kidney revealed healed chronic pyelonephritis. In the renal tubules, neither necrosis not vacuolation of the lining epithelium was observed.

\section{Discussion}

In the two cases described here, widespread myocardial fibrosis was present yet the coronary arteries were patent and free from disease. Myocardial fibrosis with normal coronary vessels has been reported in occasional cases of Friedreich's ataxia (Russell, 1946), familial cardiomegaly (Evans, 1949), pseudohypertrophic progressive muscular dystrophy (Weisenfeld and Messinger, 1952), scleroderma (Weiss et al., 1943), chronic malnutrition (Gillanders, 1951; Higginson et al., 1952), hæmochromatosis (Sheldon, 1935; Swan and Dewar, 1952), and in isolated cases of thyrotoxicosis (Weller et al., 1932), syphilis (Warthin and Arbor, 1925), diphtheria (Burkhadt et al., 1938), and rheumatic fever in the absence of damage to the valves (Wood, 1950). It may also be found in endocardial fibrosis when there is an extension of the process into the underlying muscle (Bedford and Konstam, 1946; Gray, 1951). None of these conditions was present in either of the cases recorded in this paper. Myocardial fibrosis has been attributed sometimes to a late stage of Fiedler's myocarditis (isolated myocarditis), but the description of this condition varies widely from case to case and it is doubtful if it exists as a specific ætiological entity (Saphir, 1941).

The occurrence of myocardial damage in potassium deficiency has been reported in a few cases (Goodof and MacBryde, 1944; Roderiguez et al., 1950; Perkins et al., 1950; Luft et al., 1951; Keye, 1952). In most of these the lesions were acute, but in two (Perkins et al.; Roderiguez et al., Case 2) a slight degree of myocardial fibrosis was also present.

In both the cases reported in the present paper a state of severe and prolonged potassium deficiency was fully established. A close parallel exists between the myocardial changes in these cases and those constantly found in experimental potassium deficiency. In Case 1, the cellular response and the necrotic appearances of the myocardial fibres are the same as those seen during the early weeks of experimental deficiency; and the fibrosis is similar in distribution and type to that found in later weeks. On chemical analysis, the potassium content of the heart muscle was greatly reduced, and this finding is a further important correlation with the animal experiments. In Case 2, the fibrosis was extensive and the cellular response slight, these being the same appearances observed in prolonged experimental deficiency. The low potassium state in this case continued over the greater part of four years and is one of the longest so far recorded.

Caution must always be applied when comparing the effects of animal experiments to human disease and particularly in potassium deficiency where the results vary with the species. Deficiency of potassium in rats (Follis et al., 1942), mice (Liebow et al., 1941), and swine (Thomas et al., 1940), produces myocardial damage without paralysis of voluntary muscle; whereas in dogs, muscular weakness occurs without myocardial change (Smith et al., 1950). However, in man it appears that both voluntary and cardiac muscle can be affected, and there seems little doubt that in the cases reported here the potassium deficiency was the direct cause of the myocardial damage.

A state of potassium deficiency in man is usually associated with other biochemical disturbances, but there is no evidence at present that imbalance of any other electrolyte is responsible for myocardial damage. Recent experimental work, however, has shown that if excessive sodium is administered to potassium deficient rats the resulting damage is more rapid and severe; conversely, if the sodium intake is restricted the myocardial damage is retarded (Cannon et al., 1953). In Case 1, the sodium intake was large and there was evidence of sodium retention over the last three weeks of life. This event may have been a factor in the production of the acute changes found 
in the myocardial fibres. In Case 2, on the other hand, there was an abnormal loss of sodium as well as potassium in the stools, and this may have enabled the heart to withstand the potassium deficiency for a long time.

A low protein state has also been found experimentally to accelerate the myocardial damage produced by potassium deficiency (Cannon et al., 1952; French, 1952). In Case 1, a low protein state was present and may also have played a part in the production of the acute changes. In the experimental work on rats, the kidneys constantly showed dilatation of the convoluted tubules together with necrosis and vacuolation of the lining epithelium. Similar lesions have been described in two of the previously reported human cases (Perkins et al., 1950; Keye, 1952). In Case 1, only slight dilatation of the tubules was found. In Case 2, the appearances were normal apart from focal healed chronic pyelonephritis.

The several episodes of cardiac pain in Case 2 remain unaccounted for. It is conceivable that from time to time the intracellular electrolyte disturbances were sufficiently severe to cause areas of myocardial necrosis. Such a conception would explain the episodes of chest pain, the coincident electrocardiographic changes indicating cardiac infarction, and the subsequent finding at autopsy of scarring visible to the naked eye. It is of interest that in the second case described by Roderiguez et al. a large area of myocardial softening was found at autopsy, but details of the cardiac symptoms are not given and no electrocardiogram is available. In Case 1, although there were multiple focal myocardial lesions, these apparently were not extensive enough to produce cardiac pain or permanent electrocardiographic changes. The electrocardiogram was affected only by changes in the level of the serum potassium, and this applied also to the cardiogram in Case 2 before the occurrence of chest pain.

In this paper, further evidence is produced to show that potassium deficiency in man may result in damage to the myocardium. If the deficiency is severe or prolonged the damage may be considerable. These findings indicate that a low potassium state should be corrected as quickly and completely as possible in order to avoid permanent cardiac injury; and further, that experiments on potassium deficiency in the human subject should be undertaken with caution.

\section{SUMMARY}

Two cases of prolonged and severe potassium deficiency are described with particular reference to the cardiac findings before and after death.

In both cases, widespread myocardial fibrosis was present, yet the coronary artery system was patent and free from disease. In one, focal necrosis of the myocardium was also seen.

A close parallel can be drawn between the findings in these cases and those in potassium deficiency in experimental animals.

It is considered that the cardiac lesions were the direct result of potassium deficiency, and that such a deficiency should be corrected as quickly as possible if irreparable myocardial damage is to be avoided.

I wish to thank Dr. N. F. Coghill for permission to study his cases. I am indebted to Dr. A. C. Counsell for his great assistance with the pathology, to Dr. M. Lubran for advice on the biochemistry, and to Dr. Wallace Brigden for his helpful criticism of the paper. I also wish to thank Mr. D. A. Vinten for preparing the microphotographs.

\section{REFERENCES}

Bedford, D. E., and Konstam, G. L. S. (1946). Brit. Heart J., 8, 236.

Bellet, S., Nadler, C. S., Gazes, P. C., and Lanning, M. (1949). Amer. J. Med., 6, 712.

Burkhadt, E. A., Eggleston, C., and Smith, L. W. (1938). Amer. J. med. Sci., 195, 301.

Cannon, P. R., Frazier, L. E., and Hughes, R. H. (1952). Metabolism, 1, 49.

Ca,, (1953). Metabolism, 2, 297.

Clarke, N.'E., and Mosher, R. E. (1952). Circulation, 5, 907.

Darrow, D. C., and Miller, H. C. (1942). J. clin. Invest., 21, 601.

Evans, W. (1949). Brit. Heart J., 11, 68.

French, J. E. (1952). Arch. Path., 53, 485. 
Frenkel, M., Groen, J., and Willebrands, A. F. (1947). Arch. intern. Med., 80, 728.

Follis, R. H., Orent-Keiles, E., and McCollum, E. V. (1942). Amer. J. Path., 18, 29.

Gamble, A. H., Wiese, H. F., and Hansen, A. E. (1948). Pediatrics, 1, 58.

Gillanders, A. D. (1951). Brit. Heart J., 13, 177.

Goodof, I. I., and MacBryde, C. M. (1944). J. clin. Endocrin., 4, 30.

Gray, I. R. (1951). Brit. Heart J., 13, 387.

Higginson, J., Gillanders, A. D., and Murray, J. F. (1952). Brit. Heart J., 14, 213.

Iseri, L. T., Alexander, L. C., McCaughey, R. S., Boyle, A. J., and Myers, G. B. (1952). Amer. Heart J., $43,215$.

Keye, J. D. (1952). Circulation, 5, 766.

Liebow, A. A., McFarland, W. J., and Tennant, R. (1941). Yale J. Biol. and Med., 13, 523.

Lubran, M., and McAllen, P. M. (1951). Quart. J. Med., 20, 221.

Luft, R., Ringertz, N., and Sjögren, B. (1951). Acta Endocr., 7, 196.

McAllen, P. M. (1951). Brit. Heart J., 13, 159.

Perkins, J. G., Petersen, A. B., and Riley, J. A. (1950). Amer. J. Med., 8, 115.

Peschel, E., Black-Schaffer, B., and Schlayer, C. (1951). Endocrinology, 48, 399.

Ringer, S. (1883). J. Physiol., 4, 29.

Roderiguez, C. E., Wolfe, A. L., and Bergstrom, V. W. (1950). Amer. J. Clin. Path., 20, 1050.

Russell, D. S. (1946). J. Path. Bact., 58, 739.

Saphir, O. (1941). Arch. Path., 32, 1000.

Sheldon, J. H. (1935). Hamochromatosis. Oxford Univ. Press, London.

Smith, S. G., Black-Schaffer, B., and Lasater, T. E. (1950). Arch. Path., 49, 185.

Surawicz, B., and Lepeschkin, E. (1953). Circulation, 8, 801.

Swan, W. G. A., and Dewar, H. A. (1952). Brit. Heart J., 14, 117.

Thomas, R. M., Mylon, E., and Winternitz, M. C. (1940). Yale J. Biol. and Med., $12,345$.

Warthin, A. S., and Arbor, A. (1925). Amer. Heart J., 1, 1.

Weisenfeld, S., and Messinger, W. J. (1952). Amer. Heart J., 43, 170.

Weiss, S., Stead, E. A., Warren, J. V., and Bailey, O. T. (1943). Arch. intern. Med., 71, 749.

Weller, C. V., Wanstrom, R. C., Gordon, H., and Bugher, J. C. (1932). Amer. Heart J., $8,8$.

Wood, P. (1950). Diseases of the Heart and Circulation. Eyre and Spottiswoode, London. 